\title{
BOOK REVIEW,
}

\section{FORMATIVE AND EVALUATIVE VALENCES OF THE PORTFOLIO IN PROSPECTIVE TEACHERS TRAINING, (author) Crisanta-Alina MAZILESCU \\ (Valențe formative și evaluative ale portofoliului în formarea viitorilor profesori, Editura Eurostampa, Timişoara, 2019)}

\author{
Ana-Maria Aurelia PETRESCU, \\ Teacher Training Department, Valahia University Targoviste \\ Romania. \\ E-mail: anapetrescu2007@yahoo.com
}

In this volume, Mrs. Crisanta-Alina MAZILESCU, Professor PhD at the Teacher Training Department, Politehnica University of Timişoara, approaches from a double perspective - theoretical and methodological -, a modern/alternative method of teaching and evaluation, namely the portfolio. Thus, the author appreciates from the introduction that "one of the pedagogical devices that leaves the student autonomous, and allows the teacher to guide and accompany him/her in the study, and finally to evaluate him/her, is the portfolio" (Mazilescu, 2019, page 11).

Moreover, in the context of the book, the author aims to highlight the formative and evaluative role of the portfolio, in the acquisition of teaching knowledge, by students who want to become teachers.

As a structure, the book is organized in three parts, each with numerous chapters and subchapters, to which are added the annexes and bibliographic references.

The first part, entitled the Portfolio, begins with an introduction, with an argument, and continues with the definition, classification, and characterization of the portfolio, the identification of its formative and evaluative valences. This part concludes with the description, in a detailed manner, of the specific elements regarding the elaboration and content of the portfolio, considering specific disciplines as Didactics of various specializations.

In the context of the second part, Useful theory in the elaboration of the portfolio, the author starts from the identification of the basic competencies necessary for the exercise of the teaching profession and analyzes the training needs for a didactic career.

In this respect, special attention is paid to the design of training situations/activities, implementation of training activities and their evaluation. The chapter ends with the sequential description of the approach to be taken for the correct construction of a knowledge assessment tool.

The third part, entitled as suggestive as possible: Conceptual maps in pedagogy and didactics, includes 65 logical schemes (concept maps), useful for the psycho-pedagogical and methodical training of those who are preparing for the teaching career. 


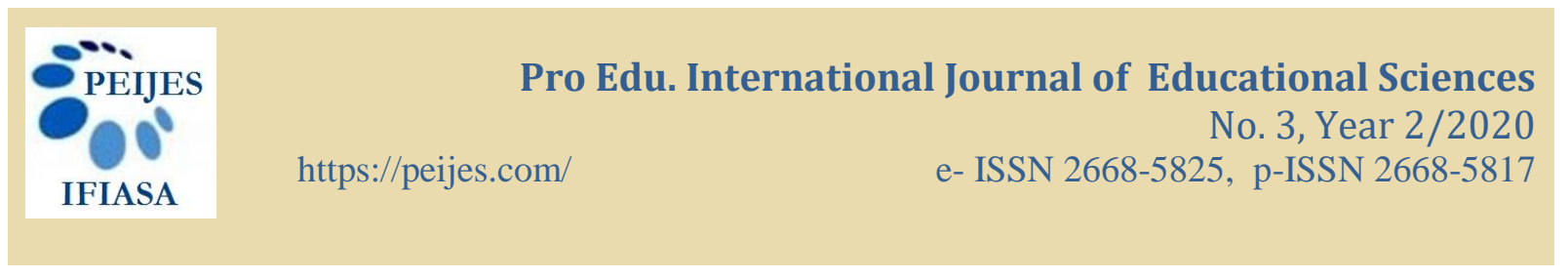

According to the author, each of those conceptual maps constitutes "a notional network that allows the schematization of a set of knowledge or concepts found in a relationship" (Mazilescu, 2019, page 111).

We cannot conclude without noticing the operational and practical value of this work, the examples presented by the author, from the perspective of her vast experience as a teacher, having a fundamental role in understanding the addressed issues.

We also appreciate the high-quality graphics, images, and numerous tables used to help the prospective teacher to understand better the content, being extremely useful in making the whole book easier to be red.

In conclusion, it can be said that the volume exploits productively the valuable expertise of the author in the field of Didactics, and vast documentation (over 60 selected bibliographic sources from international and Romanian literature), being elaborated clearly and coherently, certainly representing a valuable work for the field of Educational Sciences in general, and Didactics, in particular.

The book entitled Formative and evaluative valences of the portfolio in prospective teachers training represents a useful and necessary tool, both for the psycho-pedagogical training of bachelor and master students, who want to embrace a teaching career, but also for teachers of different specializations, in various stages of their continuous professional development. 